\title{
E-learning Courseware Development for Power Electronics Course
}

\author{
https://doi.org/10.3991/ijim.v16i03.27723 \\ Krismadinata $^{1(\bowtie)}$, Rudi Mulya ${ }^{1}$, Monika Danni Juwita ${ }^{2}$ \\ ${ }^{1}$ Centre of Energy and Power Electronics Research (CEPER), Universitas Negeri Padang, \\ Padang, Indonesia \\ ${ }^{2}$ STKIP Pangeran Antasari, Deli Serdang, Indonesia \\ krismaaft.unp.ac.id
}

\begin{abstract}
Based on the results of studies in the power electronics course, it shows that learning outcomes in the power semiconductor components and inverter are not satisfactory. Innovation in teaching materials is an alternative to increasing this competency. In this paper, an e-learning courseware for power electronics courses is developed that is valid, practical, and effective. Therefore it can improve student learning outcomes and motivation. Research and development method with the Plomp development model is employed as research methodology. The research subjects were electrical engineering education students taking power electronics course. The data analysis technique used is descriptive analysis to describe the validity, practicality, and effectiveness of the e-learning courseware. The result of the research is a learning module through e-learning that is valid, practical, and effective on the component material of semiconductor and inverter power systems that can improve student learning outcomes and learning motivation.
\end{abstract}

Keywords-E-learning module, power semiconductor components, inverter system

\section{$1 \quad$ Introduction}

The development of science and technology is very fast, especially in semiconductors. Power electronics is one of employing semiconductors. Power electronics is a branch of the science of processing and controlling electricity electronically [1]. Required renewal of teaching materials in power electronics learning [2], [3]. Power electronics competencies include (1) understanding power semiconductor components, (2) understanding the working principle of 1-phase and 3-phase uncontrolled rectifiers, (3) understanding the working principles of 1-phase and 3-phase controlled rectifiers, (4) explaining DC-DC converters, (5) explain the working principle of the inverter system, and (6) understand the AC-AC converter.

The problems that occur in learning power electronics include the difficulty of directly explaining the phenomena of various subsystems [4]; material concepts, loss of student interest [5], [6]; limited time for teachers and students in face-to-face sessions [7], [8]; low success and feedback during the learning process [9], [10], [11]. 
These problems can be overcome by using interactive learning models, problembased learning, and projects. In addition to the learning model, the use of media and modules as teaching materials can improve the quality of learning [12], [13]. Through modules, students can easily study material at home, as well as a reference.

The learning module can be developed in the form of a digital module consisting of text, images, animation, and video to visualize the material. The digital module can reduce weaknesses in printed teaching materials [14], [15], [16], can be uploaded into e-learning so that the learning process can take place anywhere and anytime, can be updated quickly, and displays interactive information compared to paper [17], [18] and Currently, researchers combine it with a project based learning model [19].

The basis of learning theory in developing learning modules through e-learning has three perspectives, namely behavioristic, cognitive, and constructivist perspectives [20]. The three learning theories are the basis for learning based on information and communication technology [21]. Behavioristic (about facts), cognitive (about processes and principles), and constructivist (about a higher level of thinking and contextual) in learning.

Success in the learning process requires good motivation (intrinsic and extrinsic) so that it can help in understanding and explaining behavior [22]. Teaching materials are also needed for students to use in achieving the goals and learning process [23], [24], [25]. Teaching materials can be in the form of books, handouts, audio, modules, and others.

The module can be used by students individually or in groups without the presence of a lecturer [26]. The benefits of the module are that it can: 1) simplify and clarify the presentation of the message so that it is not too verbal; 2) overcoming the limitations of time, space, and sensory power for both students and lecturers; 3 ) increase motivation and passion for learning; 4) develop the ability to interact directly in the environment and other sources; 5) self-study according to their abilities and interests, 6) measure or evaluate learning outcomes by themselves [26], the e-module used more effective than used print guide books [27] and students can access the study material from everywhere without any time limitation [28]. Current modules can be made in electronic form (e-module) as a result of technological developments. The research objective was to produce a learning module through e-learning on the component material of semiconductor power and inverter systems.

\section{Methods}

This type of research is research and development (R\&D) which aims to develop learning modules through e-learning on power semiconductor components and inverter systems. Adopt development model [29] which consists of three stages: (1) preliminary research which includes: analysis of the syllabus, concepts, and characteristics of students; (2) prototyping phase which includes: prototype 1 and prototype 2, and (3) assessment stage.

Desain the experimental research design used the one-group pretest-postest design method. The research subjects were 43 students of the Electrical Engineering education study program class 2LA, January-June 2018 at the Faculty of Engineering, 
Universitas Negeri Padang. The instrument for collecting data on the validity of experts and the practicality of students and lecturers used a questionnaire with a Likert scale and the instrument for collecting data on the effectiveness of the aspects of learning outcomes and student learning motivation used tests.

The data analysis technique for the validity of the learning module uses Aiken's V validity with the following steps: a) providing an answer score with a number between 1 (very unrepresentative or very irrelevant) to 5 (highly representative or very relevant); b) adding up the scores of each validator for all indicators; c) giving the percentage value of validity with the formula (1):

$$
P=\sum \frac{S}{[n(c-1)]}
$$

d) based on expert test results, the validity coefficient of Aiken's V of items whose value is $\geq 0.667$ is valid.

Then for the practicality of the learning module data analysis technique using the following steps: a) score answers with the criteria 1 (disagree), 2 (disagree), 3 (quite agree), 4 (agree), and 5 (strongly agree); b) determine the average score obtained by adding the scores obtained from many indicators; c) giving practicality value with the formula (2):

$$
P=\frac{S}{M} \times 100 \%
$$

Where NA = Final grade; $\mathrm{S}=$ score obtained; $\mathrm{M}=$ Maximum Score; $\mathrm{d}$ ) to determine the level of practicality using criteria. See Table 1.

Table 1. Practicality category

\begin{tabular}{|c|l|}
\hline Achievement Level (\%) & \multicolumn{1}{|c|}{ Category } \\
\hline $85-100$ & Very Practical \\
\hline $75-84$ & Practical \\
\hline $60-74$ & Pretty Practical \\
\hline $55-59$ & Less Practical \\
\hline $0-54$ & Not Practical \\
\hline
\end{tabular}

Furthermore, for the effectiveness of the module in terms of learning outcomes and learning motivation. For learning outcomes in terms of two aspects, namely: 1) learning completeness, and 2) differences in pre-test and post-test. 


\section{$3 \quad$ Results}

\subsection{Preliminary analysis results}

The results of the syllabus analysis of the power electronics course obtained data that the material was under the competencies that students had to achieve. The results of this syllabus analysis are depicted in Table 2.

Table 2. Results of the analysis of the power electronics learning syllabus

\begin{tabular}{|l|l|l|}
\hline \multicolumn{1}{|c|}{ Learning Outcomes } & \multicolumn{1}{|c|}{ Learning Experiences } & \multicolumn{1}{c|}{ Material/Subjects } \\
\hline $\begin{array}{l}\text { Students can understand } \\
\text { power semiconductor } \\
\text { components }\end{array}$ & $\begin{array}{l}\text { 1. Understand the scope of power } \\
\text { electronics } \\
\text { 2. Discuss applications and } \\
\text { examples of power electronics }\end{array}$ & $\begin{array}{l}\text { 1. The scope of power electronics } \\
\text { 2. Definition of power electronics } \\
\text { 3. Applications and examples of } \\
\text { the use of power electronics }\end{array}$ \\
\hline $\begin{array}{l}\text { 1. Understand the power } \\
\text { electronics components } \\
\text { the working principles } \\
\text { of 1-phase and 3-phase } \\
\text { inverters }\end{array}$ & $\begin{array}{l}\text { 2. Discuss the characteristics of } \\
\text { power electronic components }\end{array}$ & $\begin{array}{l}\text { 1. Characteristics of power } \\
\text { electronic components } \\
\text { inverters }\end{array}$ \\
\hline & $\begin{array}{l}\text { 2. Discuss the single-phase inverter principle of power } \\
\text { electronic circuits }\end{array}$ & $\begin{array}{l}\text { 1. Characteristics of the single- } \\
\text { phase inverter system } \\
\text { The working principle of the } \\
\text { single-phase inverter system }\end{array}$ \\
\hline
\end{tabular}

Result of concept analysis: The results of the analysis of the concept of the power semiconductor components and inverter material are manifested in the form of a concept map, namely the power semiconductor components concept map (Figure 1) and the inverter system concept map (Figure 2).

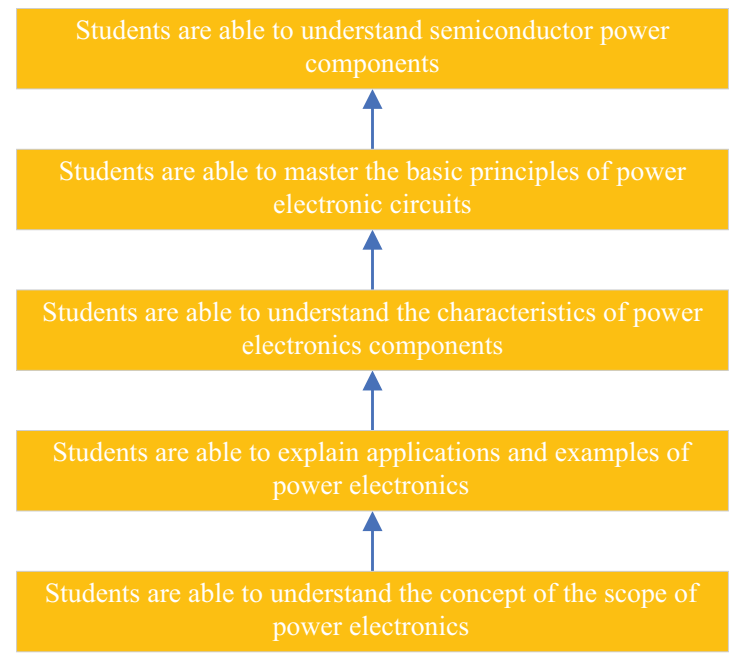

Fig. 1. Semiconductor power component concept map 


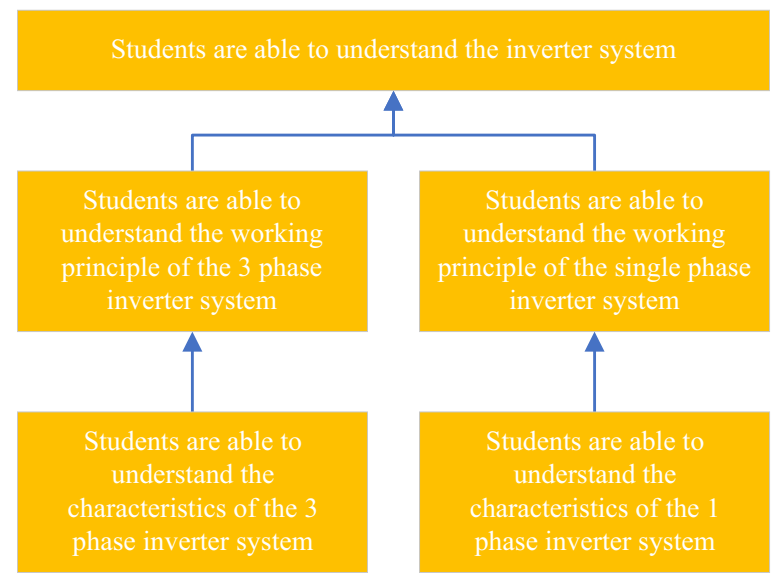

Fig. 2. Inverter system concept map

Results of student characteristics analysis: The results of the analysis of student characteristics include the level of intellectual development with an age range of 19-22 years. In the revised Bloom Taxonomy, the age lies in the create category where students can design, build, plan, produce, update, perfect, and change. This ability makes it possible to learn independently and use technology to explore learning materials.

Design results: The format of the preparation of learning modules through e-learning is based on the modified e-module systematics according to the Ministry of National Education, consisting of (a) front page, (b) content, (c) course information, (d) material content, (e) bibliography, and (f) exercises.

Frontpage: The front page describes the contents of the power electronics learning module and the learning topics. See Figures 3 and 4.

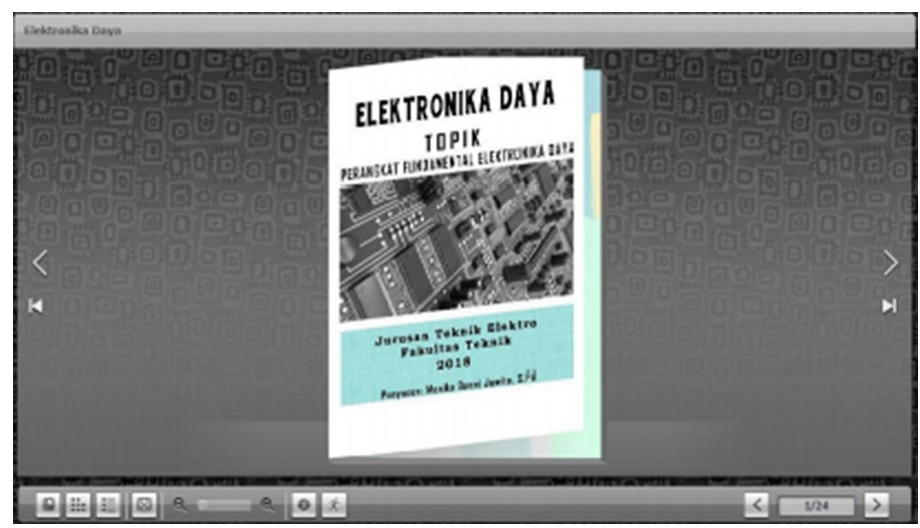

Fig. 3. The front page of the topic of power semiconductor components 


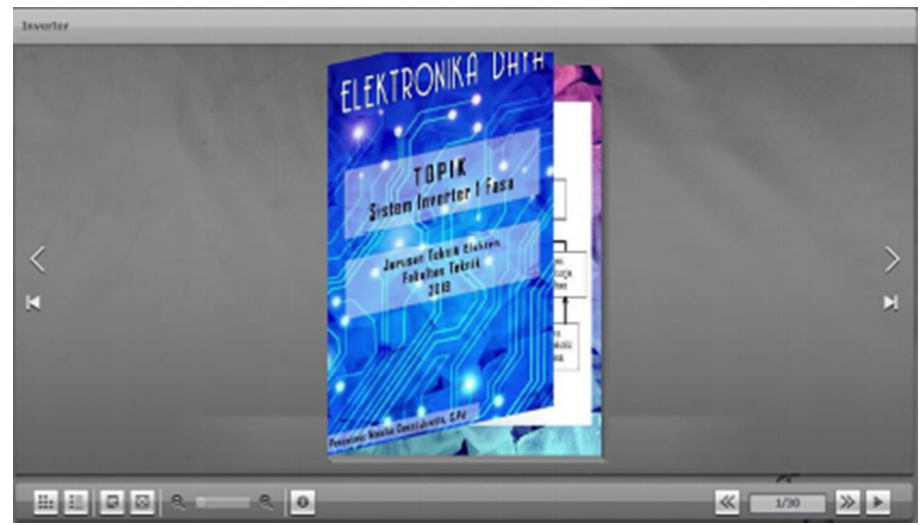

Fig. 4. Frontpage of inverter system topic

Content: Content is made to make it easier for students to know the content of the learning module. See Figure 5.

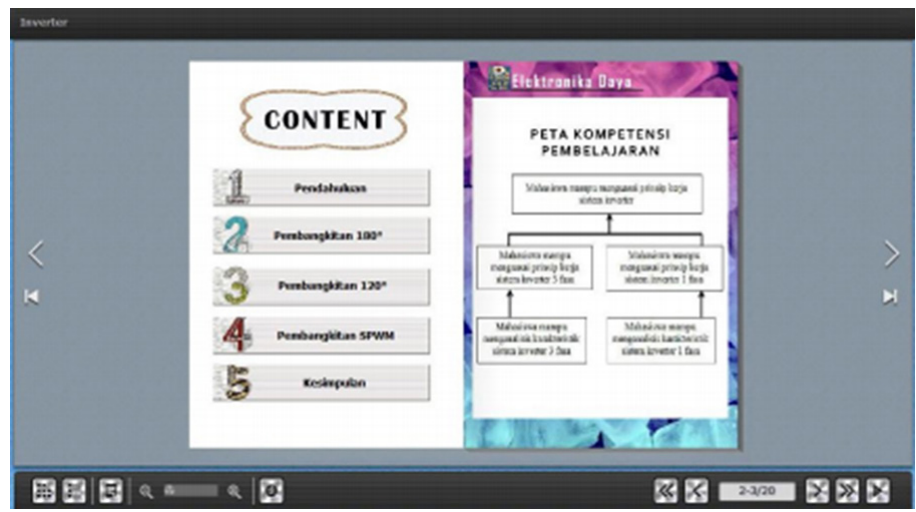

Fig. 5. Frontpage of inverter system topic

Course information: Subject information consists of competency maps, course descriptions, and learning outcomes. See Figure 6. 


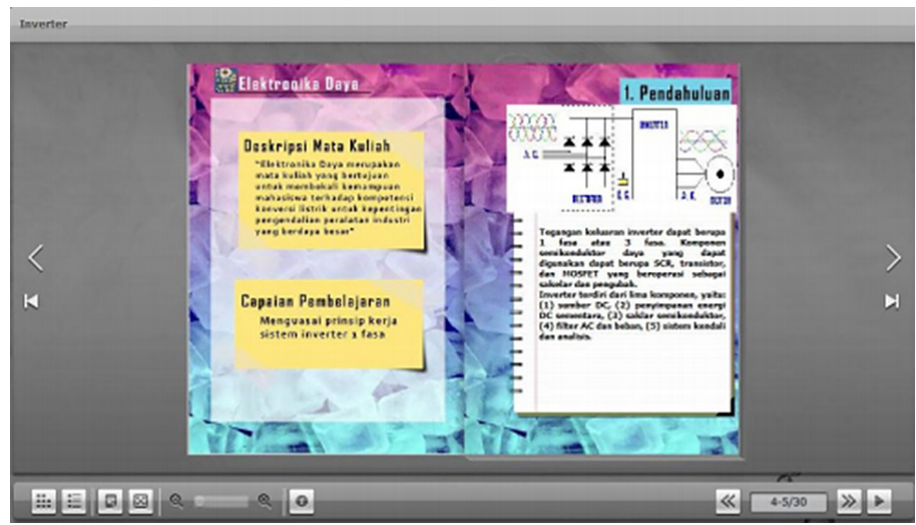

Fig. 6. Course information

Content of the material: The material is designed based on the competency map and learning outcomes contained in the syllabus. Besides being filled with text, the material is also equipped with pictures, animations, and videos. See Figure 7.

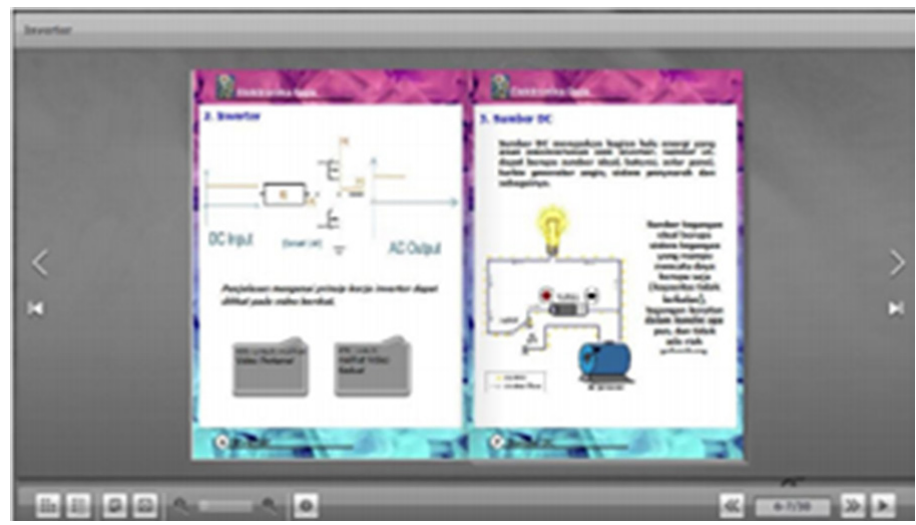

Fig. 7. Content of the material

References: The bibliography contains reference sources used to make learning modules also aims to provide information to students about the sources used. See Figure 8. 


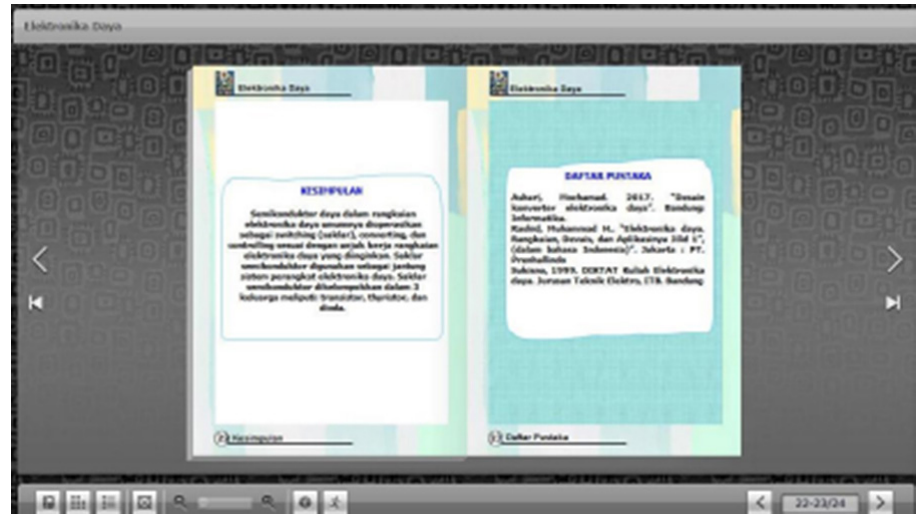

Fig. 8. Reference

Exercise view: Exercises are implemented through the UNP e-learning portal. Exercises in the form of essay questions that can display the results of the right or wrong answers. See Figure 9.

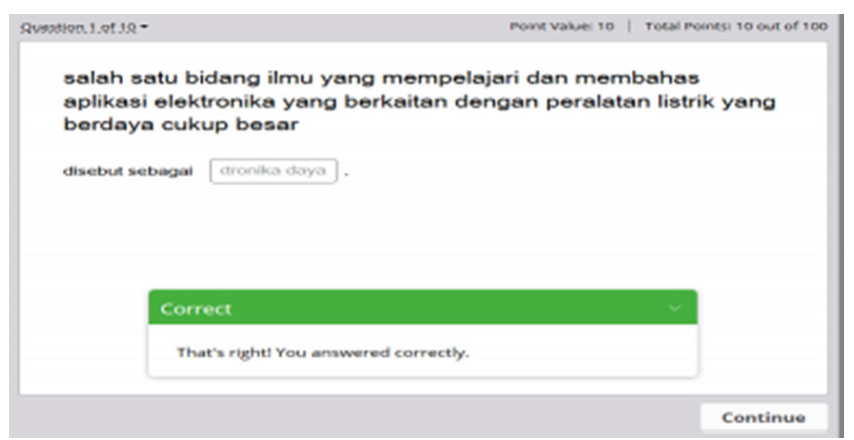

Fig. 9. Exercise view

If the questions have been answered, the results of the training scores obtained will be displayed along with the answer questions that are declared true and false. See Figure 10. 


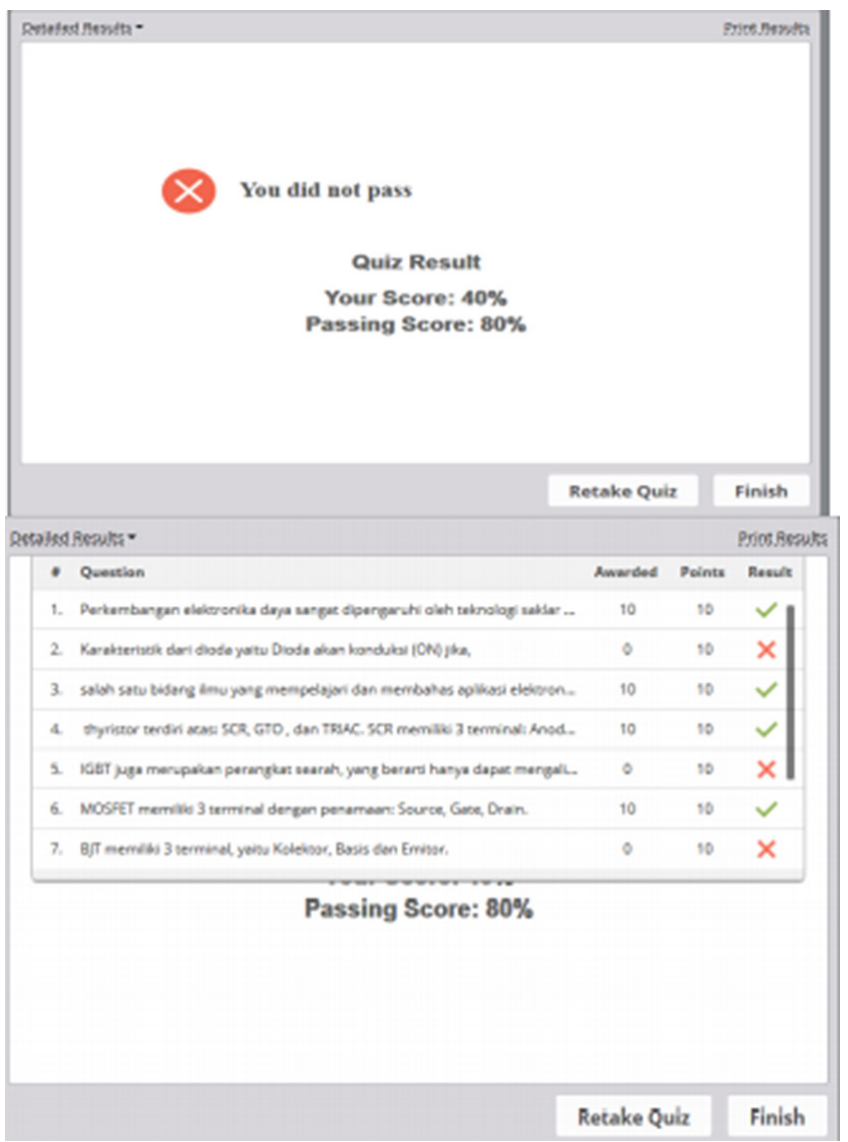

Fig. 10. Exercise scoring view

\subsection{Prototype 1 results}

The results obtained are valid values for the learning module design. See Figure 11. 


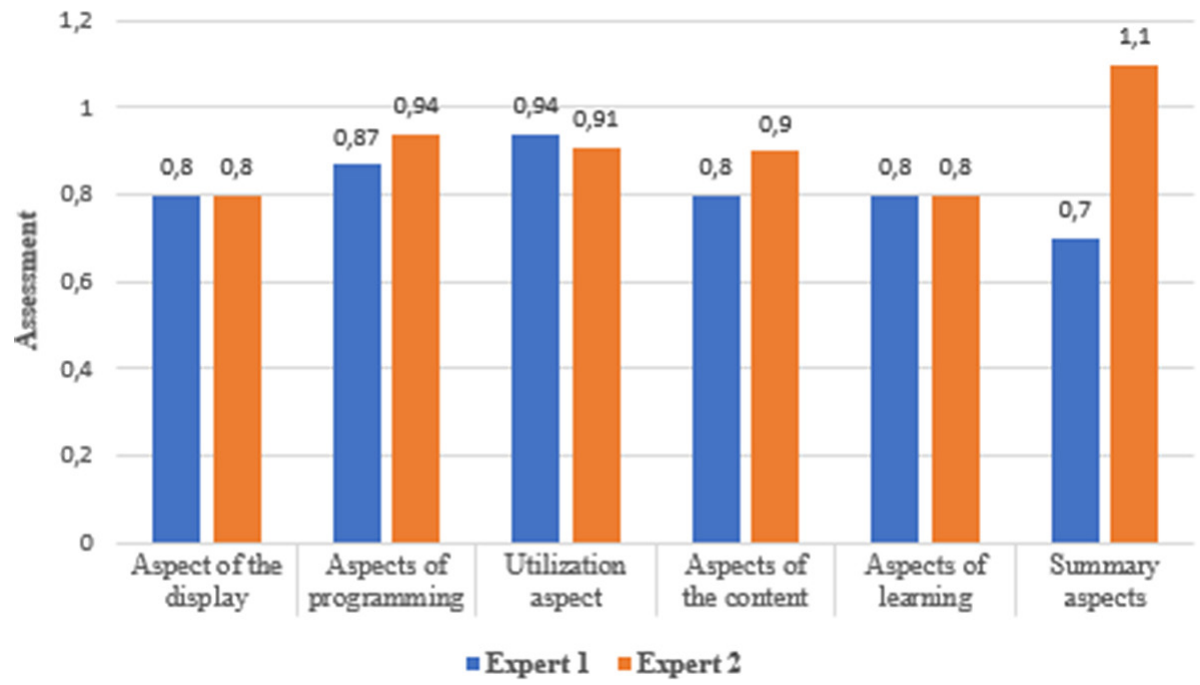

Fig. 11. The results of the validation of the e-learning module

Based on Figure 11, the results of the analysis of the validity test to media experts obtained an average aspect of $0.875>0.667$, which is categorized as valid. Furthermore, the results of validation with material experts obtained an average of $0.885>0.667$, so the material contained in the learning module through e-learning was declared valid.

\subsection{Prototype 2 results}

The results of prototype 2 to see the practicality of the lecturers and students are as follows.

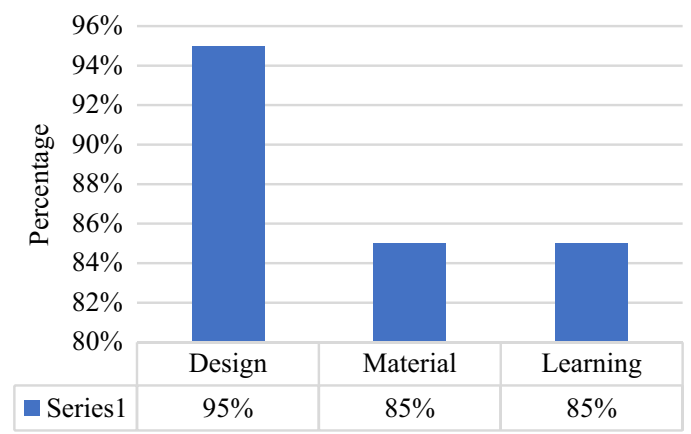

Fig. 12. Practicality based on lecturer responses

From Figure 12 the practicality based on the lecturers' responses obtained a percentage value of $88.33 \%$ with the very practical category. 


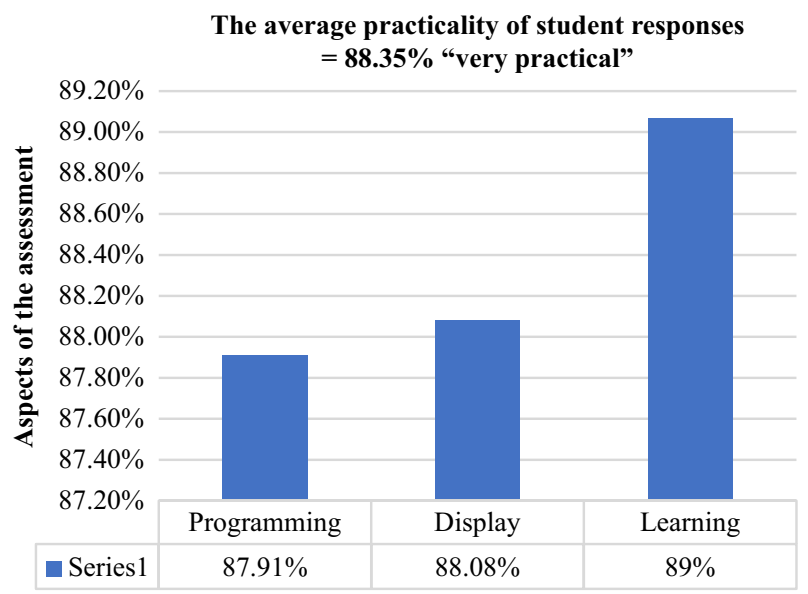

Fig. 13. Practicality based on lecturer responses

From Figure 13 practicality based on student responses obtained a percentage value of $88.35 \%$ so it can be concluded that the learning module through e-learning is included in the very practical category.

\subsection{Rating result}

The results of the assessment which are the final results of a series of learning modules are carried out four times. The data obtained from the effectiveness of learning outcomes in terms of classical completeness aspects were obtained from as many as 41 students (95.34\%) and data from the pre-test and post-test results. for learning motivation, the effectiveness test was obtained by an average of $85.56 \%$.

\section{Discussion}

\subsection{Learning module through e-learning}

Power electronics products are compulsory subjects in the Electrical Engineering Education study program. One of the competencies that must be achieved is to understand the power semiconductor components and explain the working principles of the inverter system. These competencies include an understanding of components, circuits, how to work, and the basic theory of power electronics.

Topics 1 to 2 discuss the scope of power electronics, applications for the use of power electronics, components of power electronics, and their characteristics. On topics 1 and 2, it is intended that students can understand the components of semiconductor power. Topics 3 and 4 discuss the characteristics and working principles of single-phase and 3-phase inverter systems. This learning module will later be uploaded to the UNP e-learning portal so that it can be downloaded and opened offline by students. Exercises on each topic will be applied through the UNP e-learning portal, where this exercise 
is online. The learning module through e-learning can direct students to understand the concept of material on power electronics. After the learning module through e-learning has been developed is complete, then the validity, practicality, and effectiveness of the module are tested.

\subsection{Validity}

Media validation has been carried out on three aspects, namely (1) media appearance, (2) ease of program, (3) module utilization. This validation was assessed by two validators. The average result of media validation was 0.875 with the valid category. The results of the validation of the learning module from the media aspect show that the module display is good, easy to operate and the module components are by the electronic module systematics. Based on the validation results that have been analyzed, it can be concluded that the learning module developed from the media aspect is valid and as expected. By the opinion [30] where the digital module must consider the quality and quantity of the media display so that it is easy to read.

Material validation was carried out on three aspects, namely (1) suitability of material content, (2) learning, (3) summary. This validation was assessed by two validators. The average result of material validation is 0.885 with a valid category. The results of the validation of the learning module in the material aspect show that the material in the learning module is by the learning outcomes, the content of the material is clear and the summary is displayed correctly. Based on the validation results that have been analyzed, it can be concluded that the learning module is valid from the material aspect. This is in line with the research results [31] states that the interactive module is suitable for use as a learning tool if it is seen from the aspect of the suitability of the material by the learning objectives, the up-to-date concept, and the systematics of presentation.

\subsection{Practicality}

This practicality test was carried out to reveal the readability of the learning module by lecturers and students, how easy it was to use the learning module and student interest in the learning module. The average percentage of the results of the practicality questionnaire analysis from the lecturer's point of view was $88.33 \%$ with the very practical category. The average percentage of the results of the practicality questionnaire analysis from the student's point of view is $88.35 \%$ which is very practical [32] said that a product is said to be practical if the target of achieving practicality value is more than $75 \%$.

Based on the results of the questionnaire analysis conducted with students and lecturers, it can be concluded that the learning modules that have been designed in this study can be read clearly and understood by students and lecturers, are easy to use, and students are interested in the learning modules used. The conclusion is that the learning module through e-learning is said to be practical. This is in line with the research results [33] states that the digital learning module is suitable for use as a learning resource. 


\subsection{Effectiveness}

The effectiveness of the learning module is seen from the learning outcome test after using the learning module through e-learning, it was found that $95.34 \%$ of students were declared complete, whereas many as 41 students scored above C-. The results of effectiveness are also seen from the differences in learning outcomes between before and after the application of the learning module through e-learning, where there are differences after using the learning module through e-learning. Therefore, the learning module is effective in terms of learning outcomes. By the research results [34] states that learning achievement using digital modules is significantly different from learning outcomes that do not use digital modules

This is in line with the results of research conducted by [35] that digital learning modules equipped with text, animation, and video can help students who are slow to understand the material become interested and feel happy learning so that students understand better concepts. The effectiveness of this module is also seen from the aspect of student learning motivation. This effectiveness test is seen from the aspects of intrinsic motivation and extrinsic motivation to assess the motivation included in and outside the learning situation [36]. Based on data analysis, there is average result of the effectiveness of learning motivation after using the learning module through e-learning is $85.86 \%$ in the effective category, so that the learning module through e-learning can be said to be effective in terms of learning motivation. In line with research results [37] that the virtual module is assessed to increase motivation, interest, and learning activities.

\section{Conclusion}

This research has produced an e-learning courseware for power electronics courses which contains chapter on power semiconductor components and chapter on inverters. This courseware has been tested and verified. The results show that this courseware is valid, practical, and effective. This courseware can be used to improve student learning outcomes and motivation.

It is recommended to students after using this e-learning courseware, they can be more active and motivated during learning thus encouraging self-potential in improving learning outcomes. It is recommended to lecturers who teach power electronics course, in order to help improve learning outcomes and learning motivation students, one of which is by using the learning module through e-learning that has been valid, practical, and effective in power electronics learning.

\section{Acknowledgment}

Authors gratefully acknowledge the support of The Ministry of Education, Culture, Research, and Technology of Republic Indonesia and Institute for Research and Community Services Universitas Negeri Padang under Penelitian Terapan Perguruan Tinggi Scheme. Project No. 945/UN35.136/LT/2021. 


\section{$7 \quad$ References}

[1] M. Barrenetxea Iñarra, I. Baraia Zubiaurre, I. Larrazabal Bengoetxea, and I. Zubimendi Azaceta, Power Electronic Converter Design Handbook. 2018.

[2] A. Pozo-Ruz, F. David Trujillo Aguilera, M. J. Morón, and E. Rivas, "Power Electronics Open-Source Educational Platform," J. Power Electron., vol. 12, no. 5, pp. 842-850, 2012, doi: https://doi.org/10.6113/JPE.2012.12.5.842

[3] P. Bauer and J. W. Kolar, "Teaching Power Electronics in the 21st Century," EPE J., vol. 13, no. 4, pp. 43-50, Nov. 2015, doi: https://doi.org/10.1080/09398368.2003.11463546

[4] P. Bauer and V. Fedak, "Philosophy of Interactive E-Learning for Power Electronics and Electrical Drives: A Way from Ideas to Realization," J. Power Electron., vol. 10, no. 6, pp. 587-594, 2010, doi: https://doi.org/10.6113/JPE.2010.10.6.587

[5] V. Agelidis, The Future of Power Electronics/Power Engineering Education: Challenges and Opportunities, vol. 2005. https://doi.org/10.1109/PEEW.2005.1567584

[6] S. Harb, K. Kalaldiah, A. Harb, and I. Batarseh, "Interactive JAVA Applets for Power Electronics E-learning," IEEE Power Electron. Educ. Work. 2005, vol. 2005, pp. 26-33, 2005, doi: https://doi.org/10.1109/PEEW.2005.1567588

[7] R. De Oliveira Brioschi, "Educational Innovation in Power Electronic's Education with Multimedia's Resources: Production and Implications in Education Practice," 2015 IEEE 13th Brazilian Power Electron. Conf. 1st South. Power Electron. Conf. COBEP/SPEC 2016, 2015, doi: https://doi.org/10.1109/COBEP.2015.7420157

[8] P. Cepeda, P. Ponce, and A. Molina, "Simulation to Implementation as Good Practices for Teaching Power Electronics to Undergraduate Students: Fuzzy Sliding Mode Control for DC Motors," Adv. Power Electron., vol. 2014, no. February, 2014, doi: https://doi. org $/ 10.1155 / 2014 / 697263$

[9] T. Darmayanti, M. Y. Setiani, and B. Oetojo, "E-Learning on Distance Education: A Concept That Changes Learning Methods in Higher Education in Indonesia," J. Pendidik. Terbuka dan Jarak Jauh, vol. 8, pp. 99-113, 2007.

[10] M. A. Hamid, D. Aribowo, and D. Desmira, "Development of Learning Modules of Basic Electronics-Based Problem Solving in Vocational Secondary School," J. Pendidik. Vokasi, vol. 7, no. 2, p. 149, 2017, doi: https://doi.org/10.21831/jpv.v7i2.12986

[11] Z. Zhang, C. T. Hansen, and M. A. E. Andersen, "Teaching Power Electronics with a Design-Oriented, Project-Based Learning Method at the Technical University of Denmark," IEEE Trans. Educ., vol. 59, no. 1, pp. 32-38, 2016, doi: https://doi.org/10.1109/ TE.2015.2426674

[12] J. Krosschell, Y. Li, P. Channegowda, M. Gupta, and G. Venkataramanan, "PEGO Powerpack: A Modular Power Electronics Learning Platform," 2015 IEEE 16th Work. Control Model. Power Electron. COMPEL 2015, 2015, doi: https://doi.org/10.1109/COMPEL. $\underline{2015.7236442}$

[13] N. A. Yalcin and F. Vatansever, "A Web-Based Virtual Power Electronics Laboratory," Comput. Appl. Eng. Educ., 2016, doi: https://doi.org/10.1002/cae.21673

[14] H. Ogata et al., "E-book-based Learning Analytics in University Education," Proc. 23rd Int. Conf. Comput. Educ. ICCE 2015, pp. 401-406, 2015.

[15] Darmaji et al., "E-Module based Problem Solving in Basic Physics Practicum for Science Process Skills," Int. J. Online Biomed. Eng., vol. 15, no. 15, pp. 4-17, 2019, doi: https://doi. org/10.3991/ijoe.v15i15.10942

[16] L. Solcova and M. Magdin, "Interactive Textbook-A New Tool in Off-line and On-line Education: Discovery Service for Texas A \& M University Libraries,” vol. 15, no. 3, 2016. 
[17] O. Simpson, "E-Learning and the Future of Distance Education," Distance E-Learning Transit. Learn. Innov. Technol. Soc. Challenges, no. December, pp. 107-118, 2013, doi: https://doi.org/10.1002/9781118557686.ch8

[18] N. A. Mukti and S. P. Hwa, "Malaysian Perspective: Designing Interactive Multimedia Learning Environment for Moral Values Education," Educ. Technol. Soc., vol. 7, no. 4, pp. 143-152, 2004.

[19] M. S. Mahanan, N. H. Ibrahim, J. Surif, S. Osman, M. Abd, and H. Bunyamin, "Dual Mode Module as New Innovation in Learning Chemistry: Project Based Learning Oriented," vol. 15, no. 18, pp. 47-64, 2021. https://doi.org/10.3991/ijim.v15i18.24549

[20] S. E. Smaldino, R. J. D, H. Robert, and M. Molenda, "Instructional_Technology_and_ Media_for_Learning.pdf." p. 286, 2015.

[21] A. Sadaf, T. J. Newby, and P. A. Ertmer, "Exploring Factors that Predict Preservice Teachers' Intentions to Use Web 2.0 Technologies Using Decomposed Theory of Planned Behavior," J.Res. Technol.Educ., vol.45,no.2,pp.171-196,2012, doi: https://doi.org/10.1080/15391523. 2012.10782602

[22] S. Burak, "Motivation for Instrument Education: A Study from the Perspective of Expectancy-Value and Flow Theories," no. 55, pp. 123-136, 2014. doi: https://doi.org/ $\underline{10.14689 / \text { ejer.2014.55.8 }}$

[23] L. Hakim, "Pengembangan Media Pembelajaran Pai Berbasis Augmented Reality," Lentera Pendidik. J. Ilmu Tarb. dan Kegur., vol. 21, no. 1, pp. 59-72, 2018, doi: https://doi. org/10.24252/lp.2018v21n1i6

[24] W. Dick, L. Carey, and J. O. Carey, The Systematic Design of Instruction 8 ed, 8th ed. Boston: Pearson, 2015.

[25] A. Sutiani, A. Silalahi, and M. Situmorang, "The Development of Innovative Learning Material with Problem Based Approach to Improve Students Competence in the Teaching of Physical Chemistry," no. January, 2017, doi: https://doi.org/10.2991/aisteel-17.2017.81

[26] C. Butcher, C. Davies, and M. Highton, "From Module Outline to Effective Teaching," p. 130, 2006.

[27] Astalini, Darmaji, W. Kurniawan, K. Anwar, and D. A. Kurniawan, "Effectiveness of Using E-module and E-assessment," Int. J. Interact. Mob. Technol., vol. 13, no. 9, pp. 21-39, 2019, doi: https://doi.org/10.3991/ijim.v13i09.11016

[28] D. Handayani, Elvinawati, Isnaeni, and M. Alperi, "Development of Guided Discovery Based Electronic Module for Chemical Lessons in Redox Reaction Materials," Int. J. Interact. Mob. Technol., vol. 15, no. 7, pp. 94-106, 2021, doi: https://doi.org/10.3991/ijim. v15i07.21559

[29] T. Plomp and N. Nieveen, "Educational Design Research: An Introduction," in Educational Design Research Part A: An Introduction, T. Plomp and N. Nieveen, Eds. Enschede: SLO, 2013.

[30] D. D. Prasetya, A. P. Wibawa, and T. Hirashima, "An Interactive Digital Book for Engineering Education Students,” World Trans. Eng. Technol. Educ., vol. 16, no. 1, pp. 54-59, 2018.

[31] A. K. Alghamdi, F. Kayan, and A. Hattami, "Evaluating Teaching Strategies in Higher Education from Students' Perspectives," J. Educ. Learn., vol. 11, no. 2, p. 120, 2017, doi: https:// doi.org/10.11591/edulearn.v11i2.5981

[32] S. A. Marta, S. Suparno, U. Usmeldi, and D. R. Apriyus, "Development of Computer Learning and Basic Network E-Modules," J. Pendidik. Teknol. Kejuru., vol. 3, no. 1, pp. 46-49, 2020, doi: https://doi.org/10.24036/jptk.v3i1.4023

[33] D. Serevina, V., "Development of E-Module Based on Problem Based Learning (PBL) on Heat and Temperature to Improve Student's Science Process Skill," TOJET Turkish Online J. Educ. Technol., vol. 17, no. 3, pp. 26-36, 2018. 
[34] H. Bai, A. Aman, Y. Xu, N. Orlovskaya, and M. Zhou, "Effects of Web-Based Interactive Modules on Engineering Students' Learning Motivations," Am. J. Eng. Educ., vol. 7, no. 2, pp. 83-96, 2016, doi: https://doi.org/10.19030/ajee.v7i2.9840

[35] K. Osman and T. T. Lee, "Impact of Interactive Multimedia Module with Pedagogical Agents on Students' Understanding and Motivation in the Learning of Electrochemistry," Int. J. Sci. Math. Educ., vol. 12, no. 2, pp. 395-421, 2014, doi: https://doi.org/10.1007/ s10763-013-9407-y

[36] K.-L. D. Krause, S. Bochner, and S. Duchesne, "Educational Psychology for Learning and Teaching," vol. 2nd. pp. xxv, p. 574, 2006.

[37] Q. S. Anandari, E. F. Kurniawati, S. O. Piyana, L. G. Melinda, R. Meidiawati, and M. R. Fajar, "Development of Electronic Module: Student Learning Motivation Using the Application of Ethnoconstructivism-Based Flipbook Kvisoft," J. Pedagog., vol. 06, no. 02, pp. 416-436, 2019.

\section{Authors}

Krismadinata was born in Padang Indonesia. He received the B.Eng. degree from Universitas Andalas, Padang, Indonesia, in 2000 and the M.Eng. degree from the Institute of Technology Bandung, Indonesia, in 2004 and the Ph.D. degree from the University of Malaya, Kuala Lumpur, Malaysia, in 2012, and Post-doctoral at UMPEDAC within 2012-2014. He was one of awardees ASEAN-INDIA Research Training Fellowship in 2019. He is currently with the Department of Electrical Engineering, Universitas Negeri Padang, where he is also a professional engineer and the Director of Center for Energy and Power Electronics Research Universitas Negeri Padang. Dr. Kris has international patents and also as reviewer for many international journals in electrical engineering and energy fileds. He is actively involved in consulting on renewable energy projects. His research interests are power electronics, control system and renewable energy.

Rudi Mulya is a Ph.D student at Department of vocational technology education Faculty of Engineering, Universitas Negeri Padang. He received the B.Eng. degree from Departement of Electrical Engineeing Universitas Andalas Padang in 2008 and M.Com degree from UPI YPTK Padang Indonesia in 2013 and 2018 respectively. E-mail: rudimuly4@gmail.com

Monika Danni Juwita is a Senior Lecturer at the STKIP Pangeran Antasari, Sumatera Utara. She received the B.Eng.Ed and M.Eng.Ed degrees from Universitas Negeri Padang Indonesia, in 2013 and 2018 respectively.

Article submitted 2021-10-21. Resubmitted 2021-11-18. Final acceptance 2021-11-19. Final version published as submitted by the authors. 